\title{
Institutional, genre and discursive characteristics of British restaurant online discourse
}

\author{
N.L. Shamne \\ Department of Germanic and Romance philology \\ Volgograd State University \\ Volgograd, Russia \\ nikolay.shamne@volsu.ru
}

\author{
E.B. Pavlova \\ Department of Foreign Communication \\ Volgograd State University \\ Volgograd, Russia \\ e.b.pavlova@volsu.ru
}

\begin{abstract}
The article, basing on the case study of London restaurant websites of different price range, deals thoroughly with such institutional features of British Restaurant online discourse as members, chronotope, purpose, values, strategies and tactics, material (subject areas). It briefly characterizes the variety of restaurant online discourse and gives some patterns of intertextuality usage in describing the concept of restaurant, interior, cuisine specialties. The authors note that British restaurant online discourse offers great opportunities for the use of Internet communication; it allows the emergence of trends that determine the main vectors of the global restaurant online discourse development. Particular attention is paid to the description of typical discursive formulas used in standard situations of communication. The article proposes a classification of institutional discursive formulas, which includes informative (containing factual information), informative and preventive (containing factual information and warnings) and informative and presentational (containing factual and evaluative information) clichéd statements. The authors conclude that British restaurant online discourse is an institutional phenomenon characterized by a special mass media chronotope, by the presence of hypertext space, by the creolization of texts, and by the stable set of discursive formulas corresponding to standard institutional communication situations. The article contributes to the development of discoursology and the theory of institutional types of discourse.
\end{abstract}

Keywords-text, discourse, British restaurant online discourse; institutional discourse, typology, genre and discursive characteristics

\section{INTRODUCTION}

On the one hand, the appeal to the study of Englishlanguage restaurant discourse is due to the need for studying of a group of so-called institutional discourses, among which restaurant Internet discourse is one of the most promising research areas. The relevance of the chosen topic is also determined by the importance of addressing such controversial issues as delimitation of restaurant online discourse from other types of culinary and gastronomic Internet communication, establishing the genre specificity of an English-language restaurant website, as well as the repertoire of discursive formulas and leading language tools that form the linguopragmatic potential of English-language restaurant websites.
On the other hand, it is challenging to study Englishlanguage restaurant websites as a special type of hypertext. In this regard, English-language websites of British food and beverage companies are of particular interest, because they reflect the latest trends in global restaurant industry and demonstrate a global format of hypertext space organization which is conveyed to other linguistic cultures.

British restaurant online discourse allows us to observe the facts of intercultural interaction generally and properly, that is, it provides an opportunity to analyze the interaction between different actors of the same society of one language, and between different actors who belong to different societies and are carriers of different languages and cultures.

\section{MethodologY}

The study is based on works on the discourse of K. Aijmer [3], D. Bolinger [7], J.P. Gee [12], J. Habermas [14], D. Schiffrin [24], M. Stubbs [25], T. van Dejk [10], on pragmalinguistics of J. Austin [4], H.P. Grice [12], R. Lakoff [18], R. Rathmayr [21], D. Wunderlich [27], on the theory of intercultural communication of E. Hall, W.F. Whyte [15], K. Roth [23]; on hypertext theory of G. Landow [19], M. McLuhan [20]; on Internet communication of S. Barnes [5], D. Crystal [8], S. Herring [16], as well as in on the works of S. Berghe[6], M. Davis [9], L. Rossato [22] on the study of various types of culinary, gastronomic and restaurant discourse.

The methodological backgrounds of the study are the following: the statements of M. Jung on discourse as a virtual phenomenon, the distinction between three dimensions of discursive analysis (content analysis, analysis of argument strategies and analysis of linguistic means) represented in the works of R. Wodak [26] and N. Fairclough [11], and the differentiation of personality-oriented and status-oriented (institutional) varieties of discourse proposed by V.I. Karasik [1].

Within the framework of the study, a sociopragmalinguistic approach is applied to the analysis of institutional discourse varieties and their individual segments, formulated and tested in the works of N. L. Shamne [2]. The approach includes the interpretation of discursive practices from the point of view of the social context of communication. 
Restaurants discourse is regarded as an institutional form of communication, which is characterized by social rules and ritualized framework of functioning, moreover, it has a specific stratagem and tactical organization. Data for study are based on the original English-language websites of British public food and beverage companies (restaurants, gastropubs, pubs, cafes), focused mainly on the British and European cuisine.

\section{RESULTS}

During the research work, the authors have obtained the following results.

1. The participants of restaurant Internet discourse are addressers (agents): restaurateurs, chefs, sommeliers, pastry chefs, and restaurant critics, journalists, commentators, writers, representatives of the blogosphere that publish reviews on websites in the sections like Reviews, Latest News $\&$ Reviews. The addressees (clients) of the discourse are represented by a wide audience of website visitors (guests and critics who study the content of the site). Thus, the chef of the Jacqueline O'Donnell restaurant in the hypertext space of its website under the heading 'Read Jak's Blog' acts as an active culinary blogger representing his new culinary site, which certainly increases interest in the restaurant itself and enhances the client's activity with the help of a discursive formula 'Keep up to date with Jak':

\section{Welcome}

Hello and welcome to my new web site, here you will find lots of cooking information including recipes, cooking demonstrations dates and the general goings on of myself Chef/Patron Big Sis of The Sisters Restaurant's Glasgow, Jacqueline O'Donnell.

I hope you enjoy your visit, please contact me if you have any questions (http://jacquelineodonnell.co.uk).

This small text contains several discursive formulas that motivate potential clients to take appropriate actions: Keep up to date; welcome to my new web site; please contact me if you have any questions.

Let us consider an example of the Trinity Restaurant website hypertext space, which presents various realizations of the discourse agent in the first person: the chef of above mentioned restaurant and the chef and co-owner of The Square restaurant presents his colleague. Let us provide an example of the self-presentation speech of Trinity Restaurant chef Adam Bitt, who is also, as it can be seen from the text, a restaurateur and the author of books on cooking, a participant in culinary shows, a tutor of young chefs and a representative of the chef's dynasty:

First and foremost a chef, I am also a restaurateur and a food writer. I have also appeared on screen a number of times, as a regular on BBCl's Saturday Kitchen and numerous other cooking and lifestyle shows. I also pride myself on being a mentor to young chefs starting in the business, both at my own restaurants and also through my work with the Academy of Culinary Arts. Being born into a family of great cooks and food lovers, a career as a chef was almost inevitable and I began my career in the frenetic kitchen of the legendary Claridges Hotel at the age of 16 (http://www.trinityrestaurant.co.uk).

In the website hypertext space, next to the selfpresentation, there is a presentation characteristic of Adam Bitt, being the agent, among his colleague - the chef and the co-owner of The Square restaurant:

Personally, I think Adam is one of the great talents of London ... he's a naturally very gifted guy and has fantastic classical training. Yet he's young enough to have a desire to play with the new wizardry. His food is fun. It's modern and completely up-to-date. He deserves real success.

Philip Howard, chef and co-owner of The Square, Mayfair (http://www.trinityrestaurant.co.uk).

An expert can be the agent of restaurant discourse. Let us provide the example of authoritative opinion of Rebecca Burr, editor of Michelin Guide 2016, which is given on the presentation page of The Goring Restaurant website: The food at The Dining Room at The Goring is a really pleasing mix of British classics and lighter, more modern dishes, all prepared with great skill and understanding (Rebecca Burr, Michelin Guide Editor 2016) (http://www.thegoring.com/fooddrink/the-dining-room). The opinion of restaurant discourse agents is often reflected in the Reviews section. Thus, the advantages of the national British cuisine are emphasized in the hypertext space of The Rules restaurant. These advantages are pointed out in positive reviews of such a famous writer and restaurant critic of Britain as Thomas Henry Charles Parker Bowles, the author of five culinary books, the winner of the Guild of Food Writers 2010 award for his writings on British food. Tom Parker Bowles is known for his food reviews in restaurants throughout Britain, as well as for appearing as a judge in various television culinary shows:

English grub rules OK

\section{by Tom Parker Bowles}

Game, beef, claret... and lashings of history. Long may Rules reign over us!

A Little Englishness can go an awfully long way. And at Rules that steadfast old Covent Garden grandee, there's an awful lot of Englishness.

The Spy cartoons and photos of the Queen, the stuffed pheasants, prettily framed bucolic vistas and endless alabaster busts (http://rules.co.uk/review/tom-parker-bowles).

Restaurants websites also contain reviews of renowned culinary bloggers or columnists who can simultaneously act as agents, and as clients of restaurant discourse: but $i$ was always on a quest for really excellent old English food and at rules, the oldest restaurant in London, I finally found it. The dishes are classics, like steak and kidney pie or sticky toffee pudding, and yet, they are also local and fresh. The heads of many animals that end up on the menu have found new residence on the restaurant's wall, and the menu warns regally "game birds may contain lead shot (http://rules.co.uk/review/kerry$\underline{\text { saretsky); }}$ 
Located in the 5-star Royal Garden Hotel in Kensington, you'll find the award-winning Park Terrace Restaurant, a stylish place to grab a relaxing meal

Suze, Luxury Columnist (https://www.royalgardenhotel.co.uk).

There can be links to reviews in leading magazines and gastronomic guides on restaurants website home page: 'The Peasant is both a great gastro-pub and a brilliant restaurant' Square Meal

'You can eat stylishly here on (almost) peasant's wages' The Guardian

'No-one charting the rise of the gastro-revolution could miss the Peasant' Michelin Guide: Eating Out in Pubs

'Pink beef or lamb, perfect roast potatoes, nothing to revolt about' Tatler Restaurant Guide (The Peasant, http://www.thepeasant.co.uk).

Thus, the classical dyad 'agent-client', which refers to the participants of institutional communication, is widely represented in relation to restaurant discourse, namely: chefs, confectioners, sommeliers, restaurateurs, restaurant and culinary critics, bloggers, culinary show participants, clients, as well as representatives of the expert community.

2. Chronotop of restaurant online discourse is characterized as virtual. The website format allows combining online and offline time modes by means of hypertext organization.

3. The purpose of the restaurant online discourse meets the main goal of the restaurant business which is 'to create a permanent guest' by providing full information about the restaurant concept on a website, as well as in online reviews and reviews of representatives of the expert restaurant community.

4. The values of restaurant online discourse generally correspond to the values of British culture. As key concepts of British restaurant online discourse, influenced by the most reputable restaurateurs engaged in media communication, the authors point out TASTE, PLEASURE, HONOUR, BENEFIT, NATURAL, SEASONAL. Here are just a few examples illustrating these key concepts of British restaurant discourse: The Pig and Butcher opened its doors in 2012 and has become a bit of an Islington institution. A laid back country style pub with a stunning private dining room and honest cooking that wouldn't be out of place in the country kitchens of yesteryear (The Pig and Butcher); Sisters Kelvingrove offers a relaxed atmosphere, prime location in Finnieston, friendly staff and honest cuisine (The Sisters); But if you're after a traditional English cafe serving honest, unpretentious, good-value food combined with friendly service, then look no further (Terry's cafe); Our accompanying chunky chips are tripled cooked in traditional beef dripping for an unbeatable taste. Alongside Fish \& Chips we'll also be serving popular homemade favourites such as a rich fish pie, salmon fishcakes and prawn cocktail together with a range of seasonal specials (The Chipping Forecast); We are extremely passionate about our food with quality ingredients and freshness being the key to the taste (Baileys Fish'n'Chips);
Michelin-starred chef Michel Roux Jr and Restaurant Associates have developed a relaxed and personal gastronomic setting, using modern European cooking techniques and sourcing seasonal produce of the highest quality to create a unique menu (Roux at Parliament Square); At Natural Kitchen we love good food. Whether it is our fresh fruit \& vegetables, fish or meat from our handful of suppliers everything is selected on taste \& quality first..(Natural Kitchen); We love to share the knowledge we've gained and the pleasure of cooking local food (The Webbe's Restaurants).

5. Stratagem and tactical organization of restaurant discourse is represented by the following strategies for: creating a positive emotional mood; creating an attractive image of the restaurant; increasing client activity. Within the hypertext space of websites these strategies are represented by tactics that receive verbal and non-verbal objectifications. As an illustration of motivation tactic realization, the authors can cite text fragments represented by verbal means The Five Fields on Twitter; The Five Fields on Facebook (The Five Fields) and by means of the creolized text, in which the icons are integrated into a verbal message Join our community y f 6 roum (Rules Restaurant).

6. Topics of British restaurant online discourse include such predictable subject areas as products and their processing, dishes, drinks, atmosphere, pleasure, as well as topics specific to Internet discourse: Menu, Food, Wine, Drink, Book a table.

7. Varieties and genres of British restaurant online discourse are represented by websites, food blogs, online journalism, feedbacks, comments, reviews, interviews, restaurant Internet guides. At the same time, the website, being one of the genres, can act as a special hypertext space that unites all the above-mentioned genres.

8. Intertextuality is manifested by the reference to precedent names and texts in describing the restaurant concept, its interior and cuisine. Let us provide the example of the home page website text of Dinner by Heston Blumenthal:

Dinner began in the late 90's with Heston Blumenthal's fascination with historic gastronomy. The savoury ice creams of the late 1800s, the theatre of the Tudor dining experiences and the dishes of Alice's adventures in Wonderland all resonated with his unique approach to cooking. Dedicated to the modern day discovery and evolution of dining he realised that the excitement and obsession with food is no new modern day phenomena. Together with Ashley Palmer-Watts the two chefs created a menu that takes those discoveries and fascinations of history into a new and evolving modern dining experience. Researching 14th century cookbooks such as those by the royal chefs of King Richard II to Lewis Carroll's flights of fancy. Working with food historians, tapping into the world of the British library and the team at King Henry VIIIth Hampton Court Palace the very modern dining experience of Dinner by Heston Blumenthal was born (http://www.dinnerbyheston.co.uk/about).

Apparently, this text presents important for British culture precedent historical names (Tudors, Richard II, Henry VIII), the famous medieval cookbook of the royal cook of King 
Richard II, the fantasy novel of Lewis Carroll 'Alice's Adventures in Wonderland".

9. The discursive formulas of restaurant online discourse correspond to institutionalized utterances. On the basis of sociolinguistic interpretation of word combinations connectivity by V. I. Karasik [1], let us distinguish such formulas that are standardized for the same type of communication situations, specific to restaurant online discourse agents and designed to focus on the message content rather than its form.

A classification of discursive formulas is proposed in the article. Informative, informative-preventive and informativepresentational formulas are distinguished in accordance to this classification.

Set expressions describing features of a restaurant menu and wine list: Seasonal Inspiration Menu; clichéd word combinations containing information about the average check: $£ 85.00$ for four courses; $£ 105.00$ per person (The Ledbury), as well as special conditions for guests with children, food allergies, etc.: Regrettably we are unable to accommodate children under 5 years old (The Five Fields Restaurant); We will do all we can to accommodate guests with food allergies and intolerances (The Gilbert Scott) are distinguished as regular informative discursive formulas.

English-language restaurant online discourse, which is limited to the genre of a website, demonstrates a variety of informative-preventive formulas containing warnings related to food allergy and food intolerance: Food allergies and intolerances: before ordering, please speak to a member of staff about your requirements (The Ledbury); some changes in a menu: This is a sample menu. Dishes may change daily and with the season (The Five Fields Restaurant); the dress code requirements: We Dress Code: Elegant smart casual; no shorts... (Restaurant Gordon Ramsay); an additional service charge: A discretionary $12.5 \%$ service charge will be added to your total bill (Angler) and otherwise: All dishes may contain traces of nuts \& peanuts and our fish may contain small bones (The Queen's Head).

Informative-presentational discourse formulas reflect the trends of the restaurant business. Such global trends of restaurant business as menu / products seasonality, local products priority, traditions and innovations combining are being developed nowadays within the framework of the British restaurant online discourse. These trends are becoming the facts of transculture and the basis for development of discursive formulas that are exported to restaurant online discourse of other cultures.

THE IDEA OF SEASONNESS AND LOCAL PRODUCTS PRIORITY is realized:

1) for British food and beverage companies by the following typical discursive formulas: Seasonal ingredient; Seasonal Menu, Seasonal Inspiration Menu;

2) for Russian food and beverage companies by the following typical discursive formulas: сезонное меню; только сезонные и местные продукты, региональные продукты;
3) for French food and beverage companies by the following typical discursive formulas: les produits de saison (french restaurants, Paris);

4) for Asian food and beverage companies (English versions of websites) by the following typical discursive formulas: seasonal seafood and vegetables (japanese restaurant, Tokio);

THE IDEA OF TRADITIONS AND INNOVATIONS COMBINING is realized:

1) for British food and beverage companies by the following typical discursive formulas:

\section{Traditional cooking \& modern techniques;}

2) for Russian food and beverage companies by the following typical discursive formulas:

Традиционные и современные кухонные техники и технологии; Возрождение национальных культур; (Traditional and modern kitchen equipment and technologies; revival of national cultures;)

3) for French food and beverage companies by the following typical discursive formulas:

TRADITION FRANÇAISE ET CREATIONS COSMOPOLITES DE PARIS À LONDRE (French restaurants, Le Bristol Paris);

5) for Asian food and beverage companies (English versions of websites) - by the following typical discursive formulas:

Japanese Traditional Cuisine "WITH ENGLISH GUIDE"; traditional "Kaiseki" style Japanese cuisine (restaurant Ise Sueyoshi, Tokyo).

Based on genre understanding as the basic unit of discourse, the following speech genres are distinguished depending on the sphere of speech serving this or that kind of restaurant business, including the sphere of restaurant online communication:

1) Speech genres of advertising restaurant discourse (restaurant announcement, signboard, ad, flyer, advertisements, brochure, poster).

2) Speech genres of restaurant media discourse (commentary, interview, TV show, News \& Reviews).

3) Speech genres of restaurant online discourse (restaurant blog, online diary, restaurant guide, community, forum, restaurant, tweet, web-site).

4) Speech genres of restaurant commercial discourse (bill of lading, invoice, certificate of quality, certificate of product safety, nomenclature, price list).

5) Speech genres of restaurant business community discourse (description of restaurant dish ingredients, description of the menu, description of the process, restaurant critic, restaurant presentation, restaurant chain presentation).

A classification of addresser verbalization types in website hypertext space is proposed: 
1) Personified addresser, represented, for example, by a direct address of Heston Blumenthal: It is never easy naming a restaurant. On this occasion, I wanted something that represented our menu that is inspired by historic British gastronomy, so I searched for a name that had a bit of history, but was also fun.

In the past, the main meal -dinner-was eaten at midday, before it got too dark. But affordable candles and, later, gaslight saw dinner shift. By the mid-1800s people were dining later. People working in the cities were taking a 'lunch' to work and having their main meal at 5.00pm when they got home, while in rural areas the main meal was still taken at midday.

Even today, depending where you are in the British Isles, 'dinner' might be served at lunchtime, suppertime or, indeed, dinnertime!

This made 'Dinner' the natural choice for its typically British quirky history and linguistic playfulness. If nothing else, I hope it's easy to remember.

- Heston (http://www.dinnerbyheston.com);

2) Collective personified addresser (restaurant founder team, family, friends). This variant of the addresser is realized in hypertext space of Gordon Ramsey's restaurant and Jamie Oliver's restaurant websites.

The mission of famous Gordon Ramsay's restaurant is reported in the presentation text below under the heading 'Our Team':

\section{Our Team}

The team at Restaurant Gordon Ramsay bring a wealth of knowledge and experience from the hospitality industry worldwide, ensuring the ultimate dining experience Restaurant Gordon Ramsay (https://www.gordonramsayrestaurants.com);

3)Collective addresser (a team) with elements of personification. In this case, the addresser is presented collectively with the help of a producer, who directly creates a website of a food and beverage company in compliance with addresser's instructions in accordance with text. A team, which is fixed by a special hyperlink The Team is meant under the collective addresser 'We' in website hypertext space. At the same time, brand representatives of the collective addresser are personified as a chef, a chief sommelier, a Pastry chef, etc., for example:

\section{At Launceston Place}

A true hidden gem in South Kensington, Launceston Place serves a flamboyant and seasonally-inspired modern European menu.

Awarded two AA Rosettes in 2017, Launceston Place also won AA's 'Notable Wine List' title in 2013 - one of only seven restaurants in to receive the accolade in the UK that year as well as being awarded 'Best Wine List' at the Tatler Restaurant Awards

Head Chef
Ben Murphy joins us from The Woodford as the new Head Chef of Launceston Place. He has been named Chef to Watch 2016 by The Good Food Guide and took home the Breakthrough Chef of the Year gong at the Food \& Travel Awards-all of this within the space of a year.

Head Sommelier

Piotr has passed the Court of Master Sommeliers Advanced Sommelier exam and he is soon taking his Master Sommelier examination. This year, Piotr won the Chaine des Rotisseurs UK best young Sommelier competition. Most recently, he came in second at the A.S.I. Best Sommelier of Europe \& Africa competition 2017.

Piotr's extensive knowledge of both food and wine ensures that only the best wines are selected to accompany Head Chef Ben Murphy's exquisite food

At Launceston Place (http://www.launcestonplacerestaurant.co.uk).

4) Collective addresser (a team) without personification. In this case, a restaurant team is verbalized only by the pronoun We:

Fera, the Latin word for 'wild', reflects the powerful connection to nature that is at the heart of our restaurant.

Our menus are inspired by the rhythm of the seasons. We only use exceptional ingredients that are harvested in their prime. This is why our à la carte and tasting menus change as often as the weather in which our ingredients are grown.

Our award-wining wine list features over 700 bins, both traditional selections and a collection of natural wines, including many notable English options. The Fera bar is open to non-diners, offering the perfect opportunity to try our seasonal or classic cocktails.

At Fera Development Kitchen, our chef's table accessed through the kitchen, we invite you to join our chefs to explore new dishes and cooking techniques - an exclusive, intimate and interactive dining experience bookable for up to six people.

Fera at Claridge's is open for lunch and dinner, seven days a week

\section{Fera (http://feraatclaridges.co.uk/the-restaurant);}

Over the years, The Andover Arms has seen many changes inside and out. Since 2007 we've lovingly reinstated its best features and worked hard to restore the famous British pub atmosphere - a rare thing by today's standards.

Now we have a genuinely special place to enjoy food, drink and company and we look forward to welcoming you soon

\section{The Andover Arms (http://theandoverarms.com);}

We guarantee from hook to Hill within 48 hours! Our accompanying chunky chips are tripled cooked in traditional beef dripping for an unbeatable taste. Alongside Fish \& Chips we'll also be serving popular homemade favourites such as a rich fish pie, 
salmon fishcakes and prawn cocktail together with a range of seasonal specials.

Our fresh Cornish fish can also be simply grilled or coated in Panko breadcrumbs. We also have a fabulous gluten free beer batter, an Oil Seed Rape deep frying option, and lots of delicious side salads and greens as healthy options.

We offer accomplished seafood dishes by using the best available fresh ingredients, keeping it simple and with thorough attention to detail The Chipping Forecast (http://chippingforecast.com).

\section{Passionate team}

We take great pride in our food \& service and would love to hear your thoughts. Why not share your experience on TripAdvisor and let us know how we're doing? The Wilmington (http://www.wilmingtonclerkenwell.com).

Socio-economic, status and role, socio-demographic, social-personal discursive parameters of the addressee are distinguished in the article.

According to socio-economic parameters, the addressee is regarded as a client with a stable income of the middle social class or as a representative of the expert community, a reviewer.

According to status and role parameters, the addressee is characterized by a status inequality with respect to a food company (agent-client) or a partner status (agent / restaurateur - agent / restaurant critic, a representative of the expert community).

According to socio-demographic parameters, the addressee is characterized by age, marital status, parental status, social status.

According to social and personal parameters, the addressee is characterized by the level of education, awareness in the gastronomic area, background knowledge, practical experience, a degree of readiness for contact (book a table, leave a response, etc.).

\section{CONCLUSION}

The classification of English-language discursive formulas relevant for institutional situations of online communication is developed; the genres classification of English-language restaurant discourse is offered; the genre features of the restaurant's website are described; its discourse attributes are identified, and its genre specificity is established.

It is shown that the linguocultural potential of Englishlanguage hypertext space of British restaurants websites demonstrates a global format of hypertext space organization which is conveyed to other linguistic cultures.

It is determined that British restaurant online discourse takes the leading place in the global Internet space, and represents one of the forms of intercultural interaction. In the context of British restaurant online discourse, there are some trends towards globalization and adoption of a universal civilizational standard of restaurant trends. These trends unite national and world traditions of public eating, which become the facts of transculture and the basis for the development of discursive formulas which are conveyed to restaurant online discourse of other cultures.

\section{References}

[1] K. Aijmer, "Pragmatic markers in spoken interlanguage", Nordic Journal of English Studies, 3(1), pp. 173-190, 2004.

[2] J.L. Austin, How to Do Things with Words, Oxford, 1962.

[3] S. Barnes, Computer-Mediated Communication: Human-to-Human Communication Across the Internet. Boston, 2002.

[4] S. van. Berghe, The Language of Luxury. Opulence in Gastronomic Discourse, 1960-2000, Luxury in the Low Countries. Miscellaneous Reflections on Netherlandish Material Culture, 1500 to the Present. Brussels : ASP Publishers, pp. 239-258, 2010.

[5] D.Bolinger, Meaning and form, London: Longman, 1977.

[6] D.Crystal, Language and the Internet, Cambridge: Cambridge University Press, p. 10, 2001.

[7] M. A. Davis, Taste for New York: Restaurant Reviews, Food Discourse and the Field of Gastronomy in America, NY: New York University, 2009.

[8] T. van. Dijk, Text and Context. Explorations in the Semantics and Pragmatics of Discourse, London: Longman, 1977.

[9] N. Fairclough, Analysing Discourse: Tex tual Analysis for Social Research, London and New York: Routledge, 2003.

[10] J.P. Gee, Social Linguistics and Literacies: Ideologies in Discourses, London, 1996.

[11] H. P. Grice, Presupposition and conversational implicature, Radical Pragmatics, New York, pp. 183-198, 1981.

[12] J. Habermas, Erläuterungen zum Begriff des kommuniativen Handelns, Vorstudien und Ergänzungen zur Theorie des kommunikativen Handelns, 3. Aufl, Frankfurt a/M. : Suhrkamp, S. 571-606, 1989.

[13] E.T. Hall, Whyte, W.F. Intercultural Communication: A Guide to Men Human Organization, No. 19, pp. 5-12, 1960.

[14] S. Herring Computer-mediated discourse analysis: An approach to researching online behavior, Designing for Virtual Communities in the Service of Learning. New York, pp. 338-376, 2004.

[15] K. Böke, M. Jung, M. Wengeler (Hrsg.), Linguistische Diskursgeschichte, Öffentlicher Sprachgebrauch. Praktische und historische Perspektiven. Georg Stötzel zum 60. Geburtstag gewidmet. Opladen: Westdeutscher Verlag, S. 453-472, 1996.

[16] V.I. Karasik, "Language Circle: Personality, Concepts, Discourse" [Jazykovoj krug: lichnost', koncepty, diskurs.] Volgograd, Peremena, 2002.

[17] Lakoff, G., Johnson, M. Metaphors We Live by, Chicago: University of Chicago Press, 1990.

[18] G. P. Landow, Hypertext / Text / Theory, Baltimore, 1992.

[19] M. McLuhan, Media is a message, Toronto, London,1967.

[20] R. Rathmayr Pragmatik der Entschuldigungen. Vergleichende Untersuchung am Beispiel der russischen Sprache und Kultur, Koeln, Weimar, Wien, 1996.

[21] L. Rossato, The Discourse of British TV Cookery, Naple, 2009.

[22] K. Roth, Interkulturelle Kommunikation. In: Brednich, Rolf W. (Hg.): Grundriß der Volkskunde: Einführung in die Forschungsfelder der Europäischen Ethnologie. Sonderdruck, Berlin, 2001.

[23] N.N. Shamne, A.A. Petrova, L.N. Rebrina, M.V. Milovanova, "Fenomen pamjati i kategorija prostranstva: gnoseologicheskij i kommunikativnyj status", XLinguae European Scientific Language Inurnal vol 7 Is 2 Iune ? O 14 nn 3?_-40

[24] Schiffrin, D. Approaches to Discourse [Text] Cambridge, MA: Blackwell Publishers Inc., 1994.
/ D. Schiffrin. - 
[25] M. Stubbs, Discourse Analysis: The Sociolinguistic Analysis of Natural Language, Oxford, 1983.

[26] R. Wodak, Disorders of Discourse, London; New York, 1996.
[27] D. Wunderlich, Methodological remarks on speech act theory, Speech Act Theory and Pragmatics, Dordrecht; Boston, pp. 291-312, 1980. 